\title{
Social democracy and trade unions
}

\begin{abstract}
Social democratic roots take us back to the two great revolutions in modern western European history. The French Revolution of 1789 paved the way for a political view based on the interests of society, while the industrial revolution created the working class which, challenged by the new company organisations and capitalism, came up with the idea of forming the first trade unions as a means of protecting their interests and ensuring that they were not ignored. Workers did not have status and did not possess land, nor did they have control over the means of production. These are the main principles underlying social democracy in which the development of equality and egalitarianism have played major roles. The article goes on to discuss cause and effect relationships between social democracy and trade unions; the importance of egalitarianism as a linking ideology and practice; the necessity of the acceptance of social democracy as a condition of the existence of trade unions; and the importance of social security as a standard for social democracy and the survival of trade unions.
\end{abstract}

Keywords: social democracy, unions, roots of social democracy, roots of unions, principles of social democracy, collective bargaining, egalitarianism, equality, solidarity, marxism, welfare state, social security, human rights

\section{Introduction}

Social democracy as a political ideology was created in the late $19^{\text {th }}$ century of the socialist movement. Socialism, in the traditional sense, seeks an end to the dominance of capitalism and the capitalist system, while the Marxist sense of social democracy emphasises the absolute necessity of replacing capitalism with socialism. Social democracy seeks to reform capitalism democratically through the development of state regulation, as well as through the softening, or total removal, of the injustices inflicted by the capitalist system.

The roots of social democracy take us back to the two great revolutions in modern western European history. The French Revolution of 1789 cleared the way for political views that focused on the interests of society, rather than those of the king or church. ${ }^{1}$ This set down the basic foundations for the sovereignty of the people of the state. This allows respect for people - for workers and the working class in general and opens up possibilities for the protection of their interests, as well as for their struggle for the implementation of their rights.

1 van den Boomen, Berend Jan (2011) What is social democracy Alfred Mozer Stichting: Amsterdam. 
The other great revolution of importance for the development of social democracy is the industrial revolution. It was the industrial revolution that contributed to strengthening the role of workers and the need to respect their rights. At first, the interests of workers were ignored: a consequence of the conditions of life on the border of poverty. One of the first and most basic concerns was equality and egalitarianism. Equality scrapped injustice and banned the exploitation of workers. Socialism represents raising people up, proving them through education and culture. Early socialism, ideologically developed through the ideas of Karl Marx, found ground precisely in those climates where industrialisation had taken hold.

Social democracy began as a political movement anticipating a revolutionary change in social relations. Following the collapse of capitalism, all public funds would become a public good that belong equally to all people, with each employee working according to their ability and receiving according to earnings from work. The only form of progression in social democracy is education.

\section{Main characteristics of social democratic attitudes}

We might sum up social democracy in the following key phrases which define its parameters of activity:

1. the adoption of liberal social-democratic principles and an acceptance that political change can and should be performed peacefully and constitutionally

2. the acceptance of capitalism as the only reliable means of producing wealth, because socialism is not qualitatively different from capitalism

3. a view of capitalism as morally flawed, especially as a means for the distribution of wealth; capitalism is associated with structural inequality and poverty

4. a perception of the nation state an important unit of political rule, in the sense that states have a significant capacity to regulate economic and social life within their borders.

\section{Trade unions}

At the time of the industrial revolution in the late nineteenth and early twentieth century, the need for workers to be organised to improve their working conditions became apparent. The first set of workers, mainly in the United Kingdom and western Europe, confirmed that poor working conditions were the basis for the creation of unions.

Unions are legal entities managed in accordance with democratic principles, meaning that each member has one vote. Unions are organisations of employees, established to negotiate with the employer, and it is clear that opting for unions establishes a better status for workers, as well as in terms of the protection of their rights. Unions have evolved under the influence of social upheaval: they are the result of social progress and, as such, have as a feature that they are carriers of democratic tolerance and equality. Where unions operate, even if this implies strikes and confrontation, it is nevertheless clear that society is governed, as far as economic and social well-being is indicated in those particular circumstances, and that the apparent stability of the society and of continued social progress is therefore a guaranteed factor. 


\section{Causal effect of relations between social democracy and trade unions}

We can say that the development of both social democracy and the institutions which developed unions have one and the same foundation in the French Revolution and the industrial revolution. What is characteristic for social democrats and trade unions is that, without each other, they can not exist: the absence of social democracy automatically erases the existence of unions. Social democracy means equality, and it is this equality that is the primary function, and mode of operation, of trade unions. Where there is no real equality, unions step forward to act. (We're talking here about politically non-aligned unions - which all of them should be.)

Social democrats have historically been known as supporters of the trade union movement, as they believe that the democratic principle of checks and balances can be achieved in the sphere of employment, in which entrepreneurs / employers have a lot of power but have to hire labour to meet their requirements. ${ }^{2}$ Freedom of association for employees hired in this way facilitates collective bargaining on working conditions, wages, benefits, etc. which are relevant to their employment.

Co-operation between unions and social democratic parties in Europe have led to really valuable results for collective bargaining and the collective rights of workers, including a five-day working week, annual leave, parental leave and other rights which are today a part of the foundations of modern civilisation and which, simultaneously, are considered natural human rights. ${ }^{3}$ Social democracy is a safe haven for all the great social ideas; social democracy as the ideal creates the ideological basis of society and it also delivers freedom of operation to unions and workers. It would be more accurate to say that, in a real social democracy, unions are an essential part of the foundations rather than something which flows from such a philosophy. Social democracy is what provides a defensive shield, but also justifies the taking of operational steps, because it is the ideal political form. Limited and controlled by state capitalism, with guaranteed rights for workers, where the owner takes care of capital, the state collects taxes and other optimised forms of regular income, and the employee is fully secured and has a secure salary - this justifies the premium ranking of social democracy both in theory and in practice.

\section{Egalitarianism as root ideology and practice}

The formation of social democratic parties in western Europe began in the second half of the nineteenth century. Social democracy has Marxist foundations.

The basic social values are that people are considered equal, and class solidarity. The main focus is to improve the living conditions of the working class not only from an economic standpoint, but also from the cultural and educational one. Initially seen as an enemy, the state has now become the most important channel through which solidarity, equity and social justice, and freedom, can be gained.

2 Nikolić, M Modern social democracy Democratic Party Research and Publishing Centre: Belgrade.

3 Friedrich Ebert Stiftung Social Democracy and the trade unions in Central and Eastern Europe. 
Considering the fundamental value of equality, social democrats can be shown to follow the ideas of European humanism and not to leave behind one of the important source ideas for Marxism. There are elaborations on issues of equality and inequality, and they have also tried to show that they are significantly different from the proponents of a capitalist economy regarding their relationship with the market and their understanding of the role of the state, as well as various anti-egalitarian, anti-collectivist and neo-conservative options and concepts. At the same time, social democrats reject any extreme egalitarianism and political radicalism in striving to establish equality. The means of achieving social equality they see in properly-conceived social policy and social services, where the state has a specific and special role. ${ }^{4}$

\section{Social democracy as a condition of the existence of trade unions}

We have already argued that the aims of social democracy are not comprehensive without the social umbrella provided by a union; while the justification of the purpose of trade unions is impossible without the context provided by social democracy.

The aim of the welfare state is to ensure equality in the political, economic and social rights of the people. In order to achieve this, it is necessary to create the conditions in which all citizens might participate in the design of social policy. Social democrats believe that the achievement of social equality necessarily immediately follows the redistribution of wealth, achieved through progressive taxation, but also by taking into account economic characteristics, as well as creating an equality of conditions in general.

The orientation that is represented in the theory of social democracy consists of a reduction in social disparities and requires the creation of the conditions in which the social status of individuals may reflect their commitment, ability and overall contribution. At the same time, unions are the only regulator requiring the uniform treatment of all employees, as well as being the response mechanism in the reverse case.

The general principle that has characterised the theory of social democracy is that everyone has the right to use their knowledge and skills. The capitalist market is a reality, and for social democrats too, but they tend to use social and ethical measures to create a link between capitalism and social equity, which is essentially a necessity. Only as far as those measures are achieved, and those ethical attitudes encouraged, are the principles of social democracy respected. The state must exist and its measures must eliminate poverty and inequality, and legitimise the boundaries that ensure the stability of society, in this way reducing or minimising class conflicts. ${ }^{5}$

Importance of social security as a standard of survival for social democracy and trade unions

Social security, in its broadest sense, means the creation of equal opportunities for individuals for themselves and their families so that they can provide the living con-

4 Pejanović, S (2008) Policies Faculty of Special Education and Rehabilitation, University of Belgrade.

5 ibid. 
ditions that will give them a chance to meet their basic and associated needs. ${ }^{6}$ The basis of the organisation of the welfare state is social security. Without social security in the institutional sense, there is no social democratic society. Social security means the provision of subsistence as well as the cultural, educational and living requirements appropriate to production conditions, in which workers in general have the possibility that the performance of their regular duties underpins their future and that of their families, without having to walk the fine line of existence.

Social security also affects the observance of human rights because, for companies operating on the edge of workers' social existence, it is immoral to talk about respect for the law which, as such, involves the application of certain material standards. Social security in social democratic society implies the obligation of society to provide for each individual and guarantee physical integrity and equal rights for all individuals to have a choice in education, equality in employment, the possibility of applying for a social housing programme, and the provision of legal certainty in the event of a loss of capacity.

It is via the provision of social security that a social democratic society progressively enriches the idea of a better and safer tomorrow. This was the impetus for the creation of trade unions and the strengthening of social security within a society, because unions act as a constant watchful eye and, as such, have the task of protecting the interests of workers. And workers are the drivers of overall socio-economic progress.

\section{Conclusion}

For social democrats and the socialist movement, the core values of the main objectives pursued are in connection with the creation of a new and better order in which there will be more freedom, greater justice and equality, democracy and greater solidarity.

Under the general heading of social democrats and socialists' dogged pursuit of a 'new and better order' - in which there will be 'more freedom, greater justice and equality, democracy and greater solidarity' in corporate entities - some programmes are more elaborate than others. Thus, German social democrats say that:

Freedom means freedom for everyone, including especially those who think differently.

Justice requires 'equal freedom': that is, equality before the law and equal opportunity for political and social participation and social security. It seeks greater equality in the distribution of income, property and government, as well as access to education, training and the breeding of different cultures (multiculturalism).

Equal opportunities in life do not mean uniformity, but providing space for the development of individual skills and aspirations for all. 
Solidarity as a third, complementary basic value, without which there can be no human society, is a:

Weapon of the weak in the struggle for their rights,

by which is meant not only the:

Provision of social solidarity to those who are in trouble,

but also:

The possibility for all the peoples of the third world for a life worthy of human beings.

For Swedish social democrats, the main objective is to:

Build a society on the ideals of democracy and of equal value to all. Free and equal persons in one solidaristic society as the goal of democratic socialism (social democracy).

Equality to them means giving all people equal rights and opportunities to achieve in their lives, as well as an equal chance to influence the development of society. Equality means the right of choice and different life achievements. Solidarity means mutual dependence; it has certain rights, but it is also the responsibility of each individual to contribute to the community according to their ability to exercise those rights.

Trade unions and social democracy have the same root. There is a correlation because, without unions, there is no social democracy and since social democracy is not, by itself, able to secure the rights of workers - the founders and holders of socioeconomic progress.

\section{References}

Friedrich Ebert Stiftung Social Democracy and the trade unions in Central and Eastern Europe.

Nikolić, M Modern social democracy Democratic Party Research and Publishing Centre: Belgrade.

Pejanović, S (2008) Policies Faculty of Special Education and Rehabilitation, University of Belgrade.

van den Boomen, Berend Jan (2011) What is social democracy Alfred Mozer Stichting: Amsterdam.

Vidanović, I (2006) Dictionary of Social Work Belgrade. 